\title{
Modeling the Sediment Fill of the Upper Troy Pre-Glacial Bedrock Valley, McHenry County, Illinois, USA
}

\author{
Jodi Lau1, Jason F. Thomason"2, David H. Malone1, Eric W. Peterson'1 \\ ${ }^{1}$ Department Geography-Geology, Illinois State University, Normal, IL, USA \\ ${ }^{2}$ Illinois State Geological Survey, Champaign, IL, USA \\ Email: dhmalon@ilstu.edu
}

Received 10 May 2016; accepted 18 June 2016; published 21 June 2016

Copyright (C 2016 by authors and Scientific Research Publishing Inc.

This work is licensed under the Creative Commons Attribution International License (CC BY). http://creativecommons.org/licenses/by/4.0/

(c) (i) 0 pen Access

\section{Abstract}

The Troy Bedrock Valley (TBV) and its tributary valleys are the principal pre-glacial drainage in southern Wisconsin and northern Illinois, USA. This study focused on the headwaters of a tributary that occurs in McHenry County, IL. Drilling, geophysical surveys, and the analysis of existing geologic and water well data were used to determine the lithologic and geometric characteristics of the sediments that fill the paleovalley. A 3D geologic model of these sediments was then developed in Petrel. More than $65 \mathrm{~m}$ of Quaternary sediments filled the paleovalley. The model domain covers approximately $30 \mathrm{~km}^{2}$. The valley drains to the west and meanders, which is distinct from the straight course of the overlying modern Kishwaukee River. The sediments that filled the valley were subdivided into five units. These units include Illinois-age Glasford Formation coarsegrained proglacial outwash and alluvial deposits (GS2, GS1) and fine-grained lacustrine and diamicton deposits (G2 and G1). The Wisconsin-age Henry Formation sand and gravel cap the valley fill, and Cahokia alluvium buries everything.

\section{Keywords}

Buried Bedrock Valley, Glasford Formation, Illinois, 3D Geologic Model, Quaternary

\section{Introduction}

Within the glaciated regions of the world, buried valleys are found at various scales and confined to different stratigraphic units [1]-[3]. As a result of their size, hydrologic properties, and shallow depths, buried valleys have been intensively studied as for their potential to contain aquifers and major groundwater resources [4]-[8]. 
Although the Teays-Mahomet [9]-[11] and to a lesser extent the Troy Bedrock Valley [6] [12] [13] are well studied, details concerning the geology and hydrogeology of their many tributaries are lacking.

In northern Illinois, the Troy Bedrock Valley is a buried bedrock valley that occurs in McHenry, Boone, and DeKalb counties. Alden [14] was the first to publish information on the Troy Bedrock Valley. Originally based upon a north-south trending topographic low in southeastern Wisconsin [14], the Troy Bedrock Valley has been shown to be a major bedrock valley extending north into Illinois extend [6] [15]. Believed to be a component of the preglacial Mississippi River drainage system [16], the valley possesses an average thickness over $100 \mathrm{~m}$ and can reach thickness over $150 \mathrm{~m}$ [17]. Along the main valley, a number of tributaries have been identified [15]. Description of the sediments filling the valley ranges from fine-grained silt and diamicton to sand and gravels [6] [12] [13] [17].

McHenry County, Illinois has a keen interest in the potential water resources of the Troy Bedrock Valley and subsequent tributaries. With a population that increased from 35,000 in $1930>300,000$ in 2005, McHenry County has experienced the fastest growth of any county in Illinois [18]. McHenry County uses only groundwater for water resources. Historically, the vast majority, $75 \%$, of groundwater has been extracted from shallow wells screened in sand and gravel aquifers within 30 meters of land surface [19] [20]. Forecast indicates that by 2050, the county will need to extract an additional 30,000 to 231,000 $\mathrm{m}^{3} /$ day to meet demand [18].

Quaternary-age glacial deposits completely cover McHenry County except for a few scattered outcrops of bedrock that occur along creek beds and quarries (Figure 1 and Figure 2). These glacial sediments were deposited

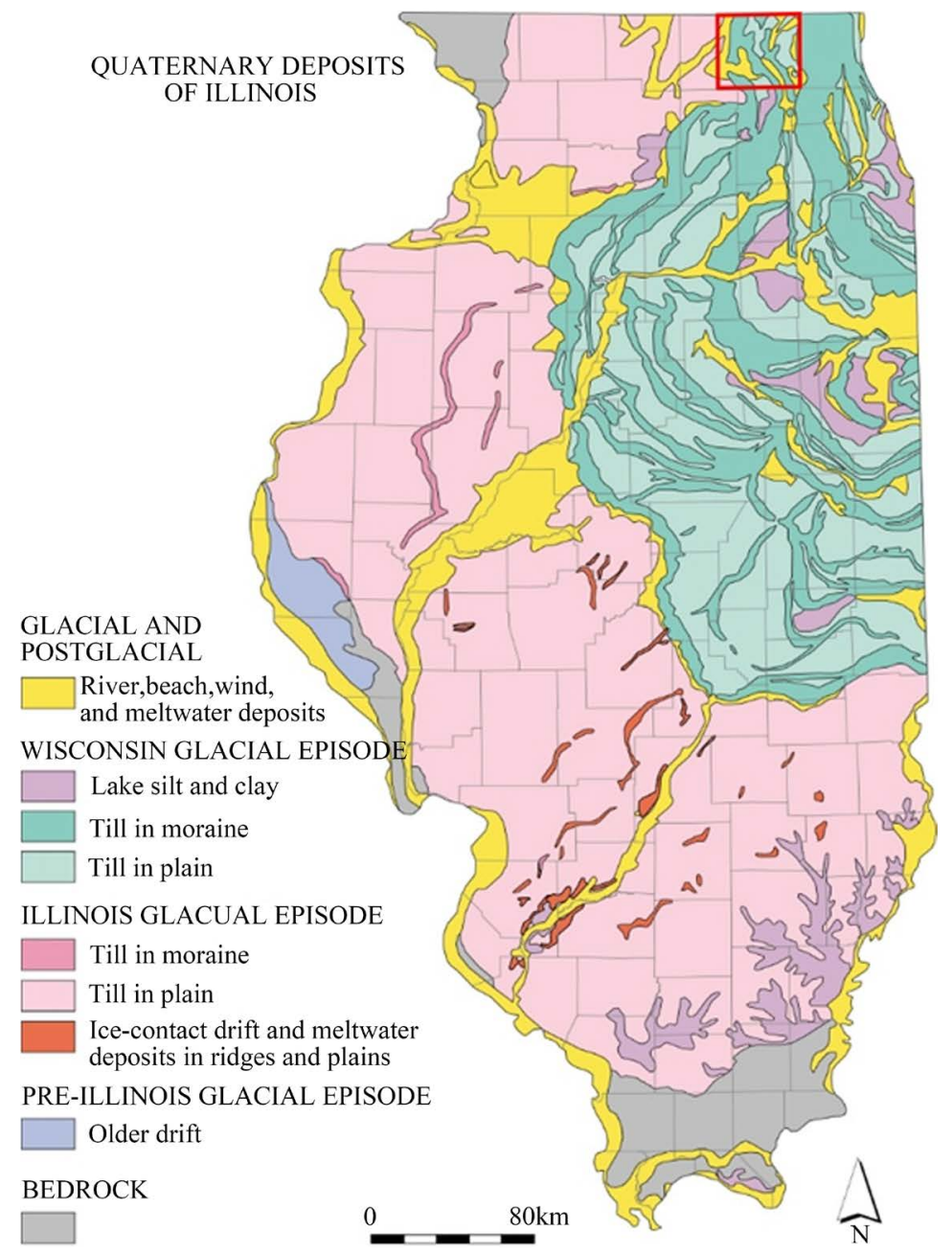

Figure 1. Surficial geologic map of Illinois showing the distribution of quaternary glacial deposits. McHenry County is outlines in red. The pale red shading within is the study area. Map is modified ISGS Staff, 2005, Quaternary deposits: Illinois State Geological Survey, ISGS $8.5 \times 11$ map series. 


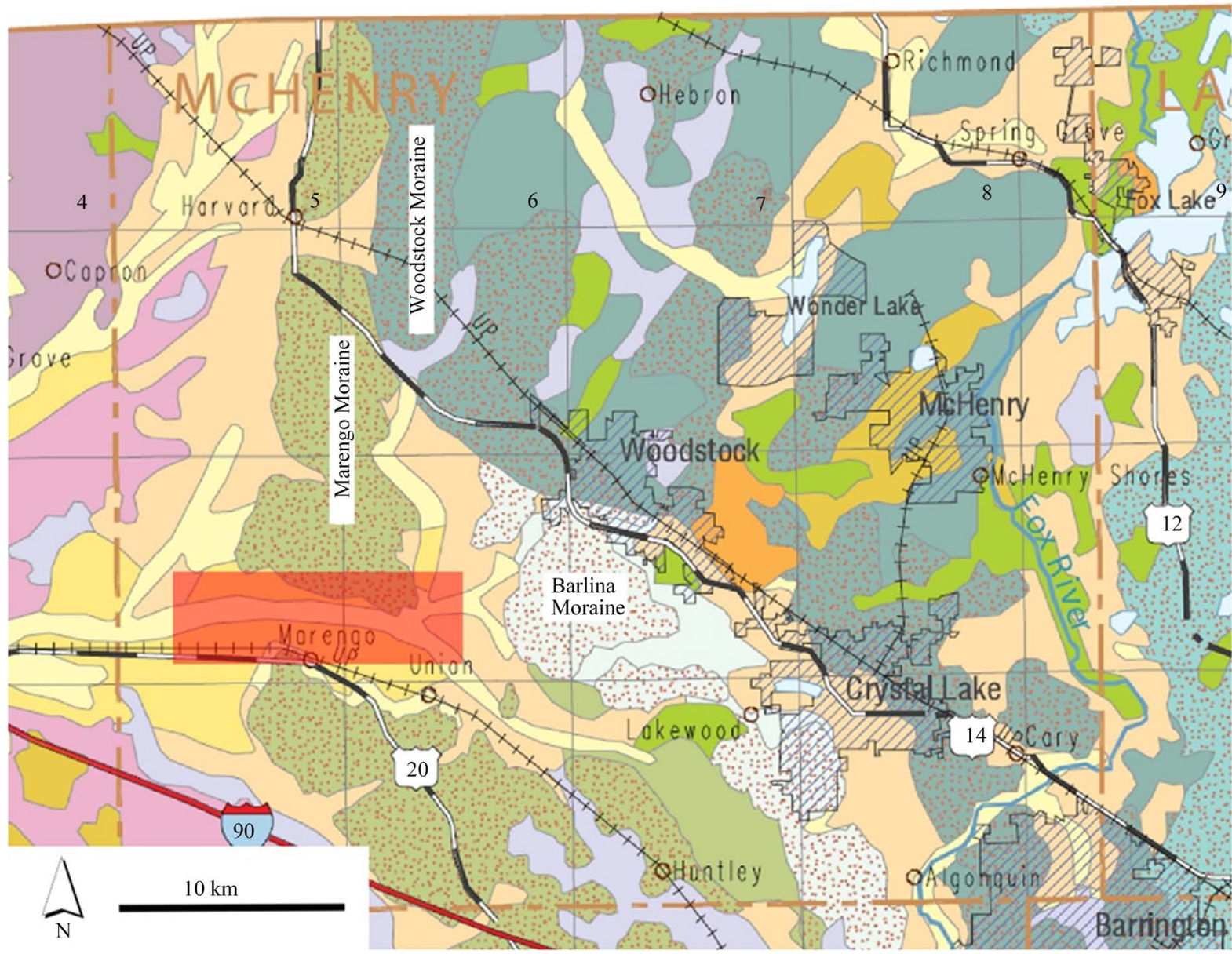

Figure 2. Surficial geologic map of McHenry County and surrounding areas (ISGS Staff, 2000). Study area is shaded in red. Positions of the major moraines are indicated. Pink = Illinoisan units; Oranges = various outwash facies of the Henry Formation; Pale purple $=$ Equality Formation, Dull green and teal $=$ Wedron Formation, Bright green $=$ Grayslake Peat; Yellow = Cahokia Alluvium.

over a time span of approximately 730,000 years by three episodes of glaciation that were separated by two periods of non-glaciation [19]. These episodes are the pre-Illinois (730,000 to 190,000 years before present), Illinois $(190,000$ to 130,000 years before present), and Wisconsin Glaciations (55,000 to 15,000 years before present). The geomorphology of the area is largely a result of Wisconsin Episode glaciation of the Laurentide Ice Sheet that advanced into northern IL during Quaternary time. The Laurentide Ice Sheet advanced from northeast to the southwest in several pulses, leaving a complex assemblage of till and outwash sand and gravel units of varying thickness and extent [21]-[26].

With the evolution of sophisticated geologic modeling software, many recent workers have strived to develop modern understanding of the 3D geometries of sediment bodies deposited in glacial setting [27]-[32]. In southwest McHenry County, a buried bedrock valley, which is a tributary of the Troy Bedrock Valley, has been filled almost completely with proglacial fluvial sediments, proglacial lacustrine sediments and ice-marginal sediments likely associated with Pre-Wisconsin Episode glaciations. Within these deposits, at least three aquifer units are present locally within the bedrock valley. Water level measurements recorded in nested-observation wells at the site suggest that these aquifers may be hydraulically connected, but the geologic setting and geometries are not known. The possibility of hydraulic connection between these aquifers has important implications for understanding the regional and local groundwater flow system and the sustainability of water resources. A first step is understanding the geology, specifically the stratigraphy of the unconsolidated sands and gravels within the buried valley aquifers. To gain insight into the stratigraphy and the potential hydrologic communication among the units a variety of field and mapping methods were used. 


\section{Previous Work}

The Quaternary deposits of McHenry County (Figure 3) have been studied for decades [19] [33]-[37]. The first comprehensive study of the Pleistocene stratigraphy of Illinois was completed by Willman and Frye [38]. Hansel and Johnson [37] reclassified the lithostratigraphic units of the Wisconsin Episode in Illinois. The most detailed study of Quaternary deposits in McHenry County by [19] focused on delineating the geology for the purposes of environmental planning. Furthermore, the surficial geology of many portions of the county has been mapped at 1:24,000 scale [34] [35] [39]-[44].

\section{Stratigraphy of Quaternary Deposits}

\subsection{Pre-Illinois Episode Stratigraphy}

The Lierele Clay of the Banner Formation is the oldest Quaternary deposit known in McHenry County. To date, it has only been located in a single stratigraphic boring taken from west central McHenry County, which records it as a 4 m thick clayey diamicton [19]. Therefore, very little is known about the extent/character of the Banner Formation.

\subsection{Illinois Episode Stratigraphy}

The Glasford Formation was initially discovered by Alden (1918) in southeastern Wisconsin beyond the extent of the Wisconsin end moraines. In this area, it is a silt-rich, calcareous gray till that is sparsely distributed below the Illinois till of the Winnebago Formation [25]. In McHenry County, IL this formation is widespread in the subsurface and is represented by four members: Kellerville Member; Fairdale Member; Oregon Member; and Belvidere Member. The Kellerville Member is the oldest unit and is a light brown, silt loam to loam diamicton. The Fairdale Member overlies the Kellerville Member and is also found in western McHenry County. The next youngest unit is the extensive Oregon Member, which consists of pinkish brown loam diamicton often contain-

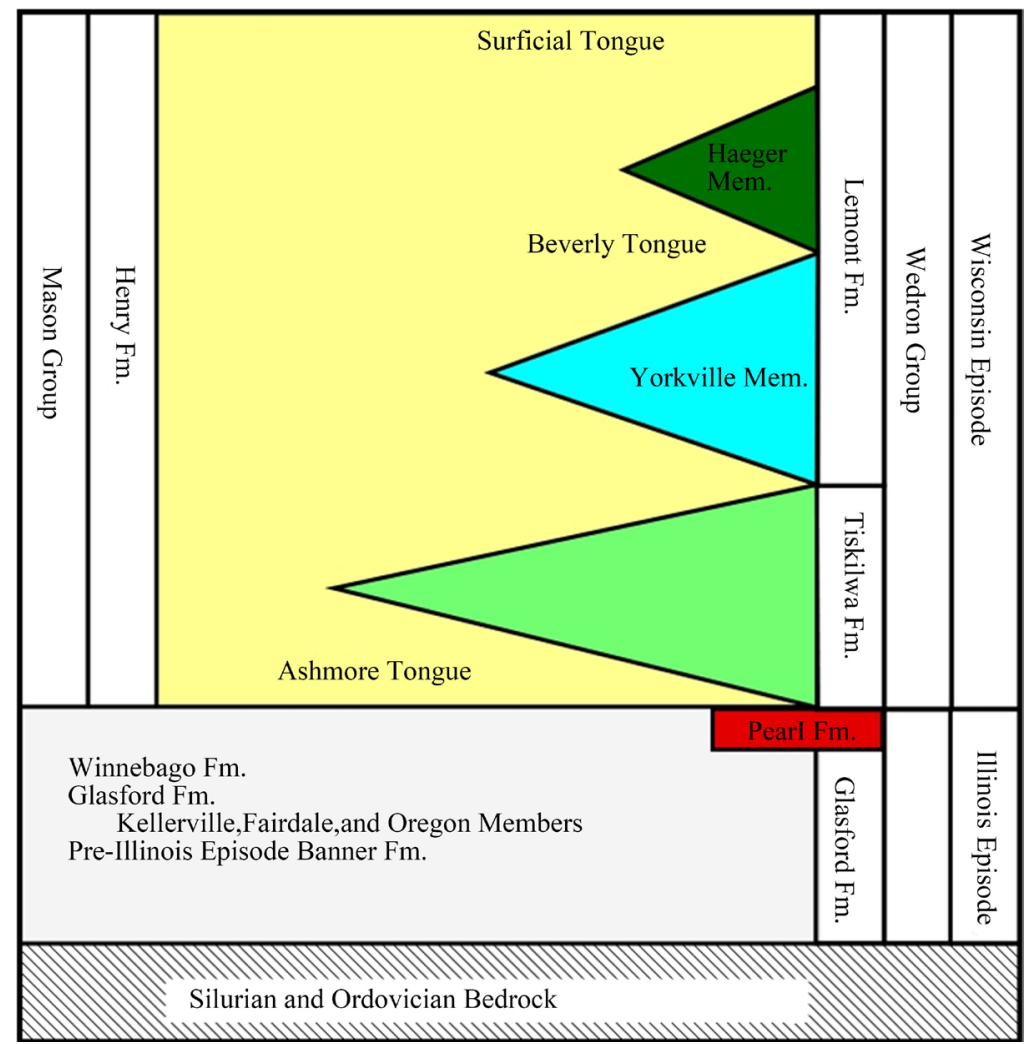

Figure 3. Stratigraphic column showing the interfingering nature of Mason and Wedron Groups Modified from Curry et al. [19]. 
ing beds of sand and gravel. The Belvidere Member is the youngest of the Glasford units and is only found in the Troy Bedrock Valley that runs north-south through the northwestern corner of McHenry County. The Belvidere Member is a gray silt loam diamicton and is related to a silty glacial lake sediment [19].

The Fairdale Member overlies the Kellerville Member and is found in western McHenry County. The next youngest unit is the extensive Oregon Member, which consists of pinkish brown loam diamicton often containing beds of sand and gravel. The Belvidere Member is the youngest of the Glasford units and is only found in the Troy Bedrock Valley that runs north-south through the northwestern corner of McHenry County. The Belvidere Member is a gray silt loam diamicton and is related to a silty glacial lake sediment [19].

In McHenry County the Winnebago Formation consists of the Argyle Till, Nimtz Till, and Capron Till Members and is found only in the far northwestern part of the county [19].

\subsection{Wisconsin Episode Stratigraphy}

During the Wisconsin Episode of glaciation, ice advanced and retreated from McHenry counties numerous times. Deposits from the Wisconsin Episode are complex assemblages of proglacial and subglacial sediments. In Illinois, the same units that were deposited by the Harvard Sublobe are categorized into two interfingering groups: the Wedron Group, which are mainly diamicton till and ice-marginal deposits, and the Mason Group, which are proglacial sediments (silt, silty clay, lake sediment, and sand and gravel outwash) (Figure 3).

The Tiskilwa Formation is a sandy, pink tan clay loam diamicton with sparse sand and gravel lenses. It was deposited by the Harvard Sublobe 18,000 - 20,000 years before present. It is the most laterally extensive glacial diamicton in the Wisconsin study area.

The sediments of the Haeger Till Member were deposited 17,000 - 19,000 years before present. It is typically a sandy loam diamicton interbedded with sand and gravel lenses and is almost always underlain by the coarse sand and gravel of the Beverly Tongue of the Henry Formation [19].

The Henry Formation is generally a stratified sand and gravel unit with lenses of silt and clay that was deposited as glacial outwash around 26,000 to 11,000 years before present [37].

The Ashmore Tongue is a medium coarse to coarse textured, stratified sand and gravel unit that underlies the Tiskilwa Formation and is interpreted to be advance-phase glacial outwash. In southeastern McHenry County it reaches a maximum thickness of about $30 \mathrm{~m}$ [19]. The Beverly Tongue underlies the Haeger Member of the Lemont Formation and is a coarsening upward sand and gravel unit interpreted as advance-phase outwash. This deposit is often mined for aggregate [19].

The Cahokia Formation is a modern alluvium that is present along modern streams such as the Kishwaukee River in McHenry County. It dominantly consists of silt, clay, and clay sand [19] [38].

\section{Methodology}

A variety of high-resolution data were collected in collaboration with the Illinois State Geological Survey (ISGS) and used for interpreting the geologic setting of this study area. These included five continuous core geologic borings, downhole geophysical measurements of natural gamma radiation, temperature, and electrical resistivity, and coupled profiles of 2D seismic and 2D electrical resistivity along a single transect. Furthermore, to help better understand the groundwater flow system, hydraulic data were collected such as head measurements, groundwater chemistry, and pumping test data. In addition, historical water well records and elevation models of land surface LIDAR data and the bedrock surface were available. Table 1 includes all descriptive parameters for the 10 cross-sections as well as the interpreted seismic profile.

One of the geologic borings (GARP-09-02) was located in the center of the bedrock valley and was used as the key boring for geologic interpretation (Figure 4). The other geologic borings were located throughout the bedrock valley within the approximately $30 \mathrm{~km}^{2}$ study area (Figure 5).

Water well data and geologic boring data were viewed in ESRI ArcScene as symbolized 3D cylinders. In this area of the county, water well data are sparse. Thus, most geologic interpretation was based on the high-resolution geologic borings. 3D visualization of the geologic data was critical for better understanding the geologic setting, but due to the sparseness of water well data within this study area, final geologic interpretations were conducted within 2D cross sections, rather than within a 3D visualization environment. Ten cross-sections were interpreted from Curry et al. [19].

Images of these cross-sections were imported into Petrel2010 and georeferenced to build fence diagrams 


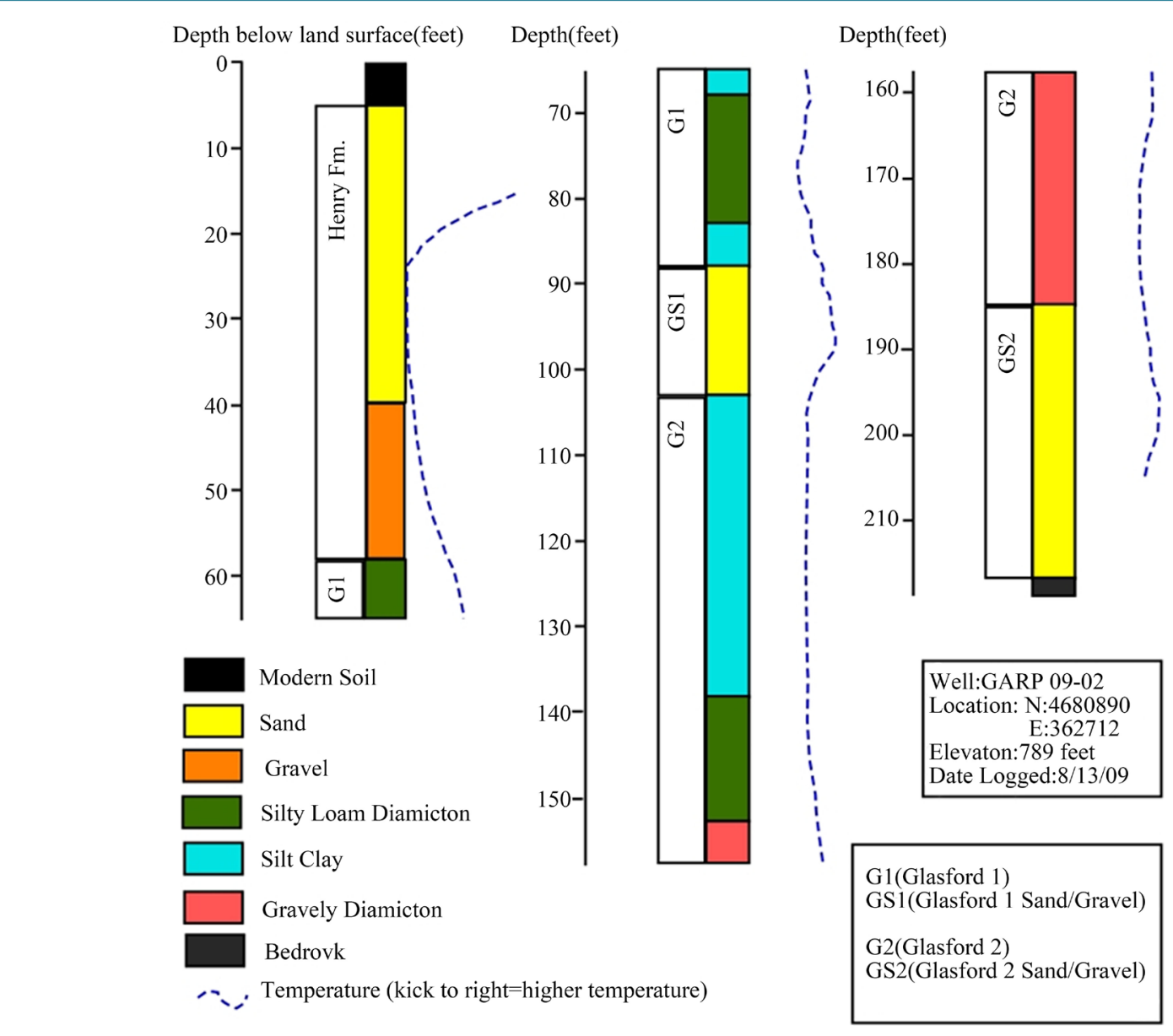

Depth(feet)

Figure 4. Lithologic log for well GARP 09-02, including temperature log.

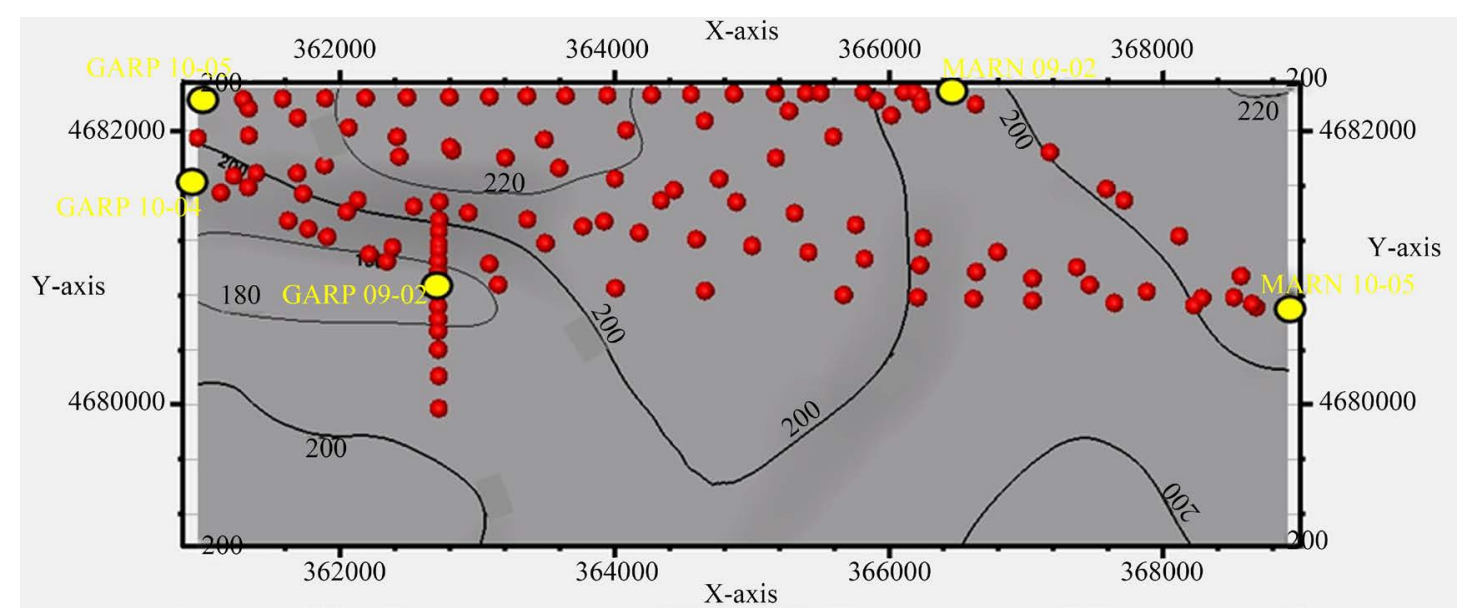

Figure 5. Location of the wells within the study area. The gray background is a structure contour map of the bedrock surface with a contour interval of $20 \mathrm{~m}$. The red dots represent locations of synthetic well data and the yellow dots represent the 5 control borings: GARP 09-02, GARP10-04, GARP 10-05, MARN 09-02, and MARN 10-05. The x-axis is northings for UTM Zone $16 \mathrm{~N}$ coordinates and the $\mathrm{y}$-axis are eastings UTM Zone $16 \mathrm{~N}$ coordinates.

(Figure 6). The geologic borings were the highest quality data available; thus, cross-sections were constructed to primarily intersect the locations of those borings. To allow mapping control between the five geologic borings, 130 synthetic boreholes were created along the cross-sections at intervals ranging from $50 \mathrm{~m}$ to $400 \mathrm{~m}$. An 


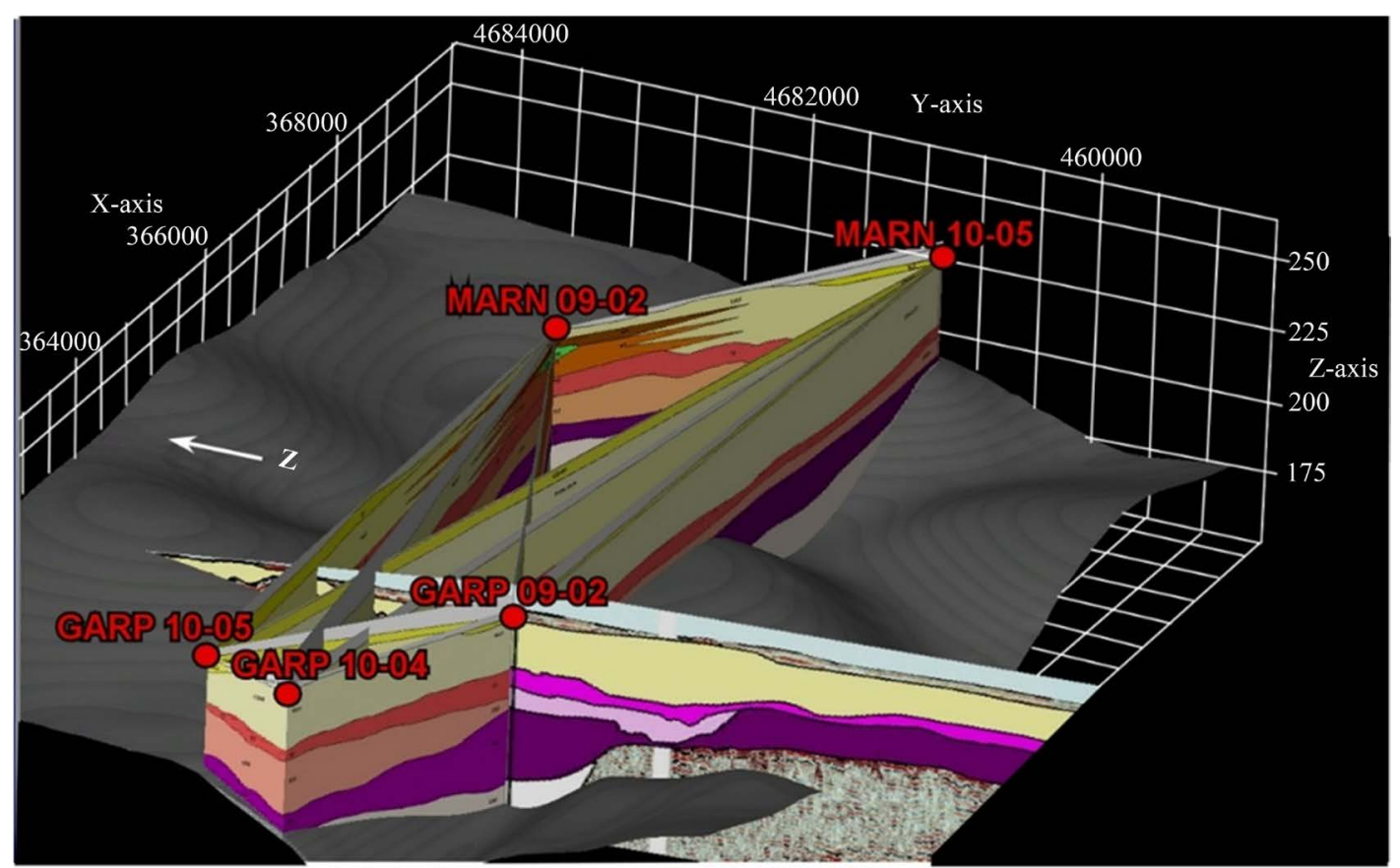

Figure 6. Fence diagram of cross-sections and interpreted seismic profile generated in Petrel. 5 control borings symbolized as red dots. $\mathrm{X}$ and $\mathrm{Y}$ dimensions are UTM grid lines.

Table 1. Key to geology and axes for all cross-sections and seismic profile.

\begin{tabular}{cc} 
Key & \\
X-Axis & Distace between wells in feet \\
Y-Axis & Elevation above MSL in feet \\
Vertical Exaggeration & 25 \\
Qal (Cahokia Formation) & Yellow \\
Hen 1 (Henry Formation) & Pale Yellow \\
Hb (Beverly Tongue) & Brown \\
Wt (Tiskilwa) & Green \\
Ha (Ashmore Tongue) & Tan \\
G1 (Glasford 1) & Pink \\
GS1 (Glasford 1 Sand/Gravel) & Salmon \\
G2 (Glasford 2) & Purple \\
GS2 (Glasford 2 Sand/Gravel) & White \\
Bedrock & Rectangles \\
\hline
\end{tabular}

additional 18 synthetic boreholes were created along the seismic profile of Thorne Road (Figure 7). The use synthetic boreholes were required as interpreted point data input into 3D modeling software (Petrel), which has been shown as an effective method to help establish the 3D model [45]-[47]. The synthetic boreholes were developed and interpreted from the cross sections in Curry et al. [19]. Table 2 includes all descriptive parameters for Petrel interpretations. 

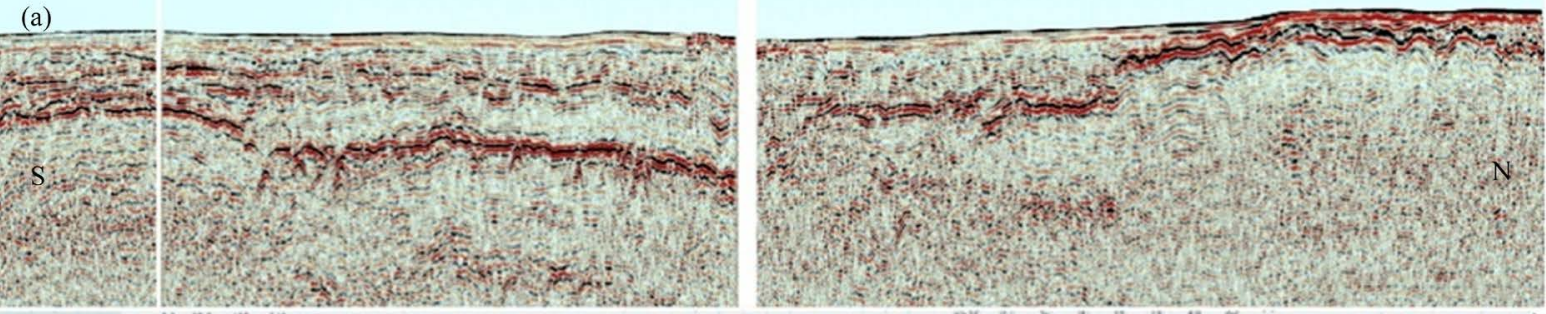

(b)

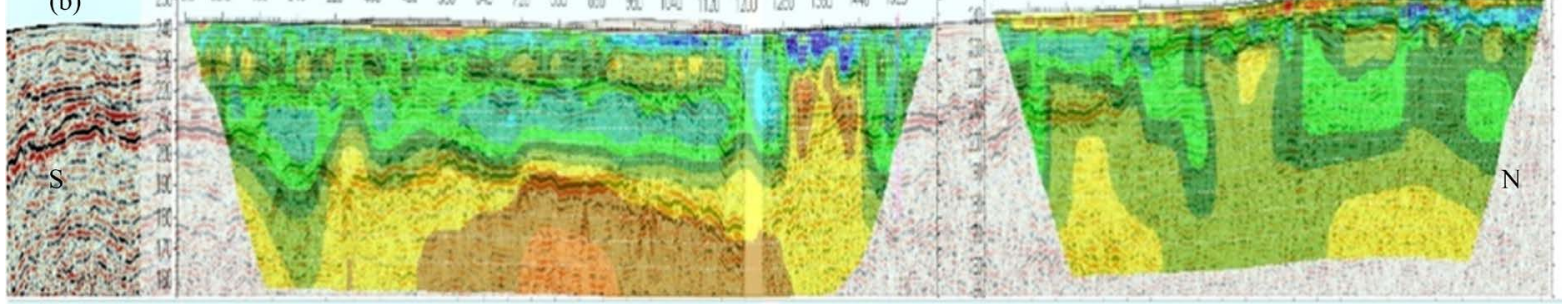

(c)

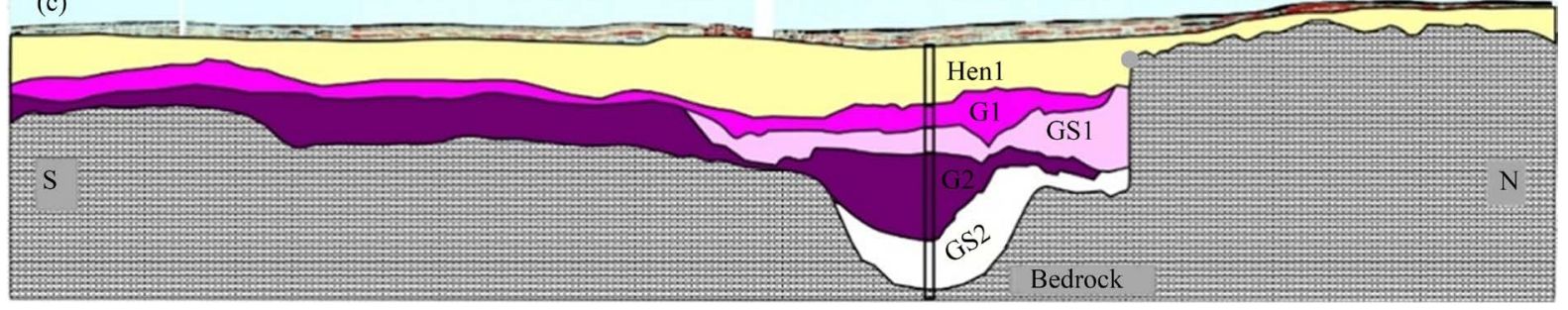

Figure 7. South-north profiles of Thorne Road geophysical data. (a) Uninterpreted seismic profile; (b) Electrical resistivity profile; (c) Interpreted seismic profile.

Table 2. Key to geology and axes for all Petrel screenshots unless otherwise noted.

\begin{tabular}{cc}
\hline Key & \\
X-Axis & UTM Zone 16 N horizontal grid value \\
Y-Axis & UTM Zone 16 N vertical grid value \\
Z-Axis & Elevation above MSL in meters \\
Vertical Exaggeration & 25 \\
Henry Formation & Orange \\
G1 (Glasford Formation 1) & Green \\
GS1 (Glasford Formation Sand/Gravel 1) & Brown \\
G2 (Glasford Formation 2) & Blue \\
GS2 (Glasford Formation Sand/Gravel 2) & Red \\
Bedrock & Grey \\
\hline
\end{tabular}

To construct the 3D geologic model in Petrel, point data from the stratigraphic picks were used as well tops that were used to interpolate the top surface of each unit. Microsoft Excel was used to manage and control borehole data and virtual borehole data. Based on the data density and data quality, five lithostratigraphic units were mappable in this study area. In stratigraphic order from youngest to oldest, these units are: Henry Formation (Hen1); Glasford Formation 1 (G1), Glasford Formation Sand/Gravel (GS1), Glasford Formation 2 (G2), and Glasford Formation Sand/Gravel 2 (GS2). The Beverly Tongue (Hb), Tiskilwa Formation (Wt), and Ashmore Tongue (Ha) are only identifiable in boring MARN 09-02 and so were grouped with the Henry Formation for modeling purposes. These surfaces were used in Petrel to construct the 3D geologic model. In Petrel, to properly model the contact relationships at the unconformable bottom of the Quaternary deposits, the bedrock surface was set as a "base horizon". Since the data set for this model produce horizons that do not intersect, all other 
surfaces were set as "conformable horizons".

The outermost extents of the fence diagrams and the northernmost $2000 \mathrm{~m}$ of the seismic profile of Thorne Road were used to delineate the model boundaries. The model measures $9.2 \mathrm{~km}$ east to west by $3.2 \mathrm{~km}$ north to south and reaches a maximum thickness of $70 \mathrm{~m}$ in the buried bedrock valley located (Figure 8). The total model domain covers approximately $30 \mathrm{~km}^{2}$.

\section{Results and Discussion}

\subsection{Distribution of Stratigraphic Units}

The 3D model consisted of five lithostratigraphic units (GS2, G2, GS1, G1, Henry Fm.) and a bedrock surface for the base. These units represent a general geologic framework associated with the infilling of the bedrock valley that occurred during Pre-Wisconsin Episode glaciations and are consistent with what has been observed within the Troy Bedrock Valley [6]. These units include sequences of coarse-grained proglacial outwash and alluvial deposits (GS2, GS1, and Henry Fm.) and fine-grained lacustrine and diamicton deposits (G2 and G1).

The Glasford Formation was modeled as four subunits as follows: G1; GS1; G2; and GS2. These deposits fill the majority of the bedrock valley and are likely associated with multiple glacial events. G1 is the uppermost diamicton and likely represents the Oregon Member. GS1 is interpreted as an outwash gravel deposit associated with the Oregon Member. G2 is the lowermost fine-grained deposit and generally represents older Illinois Episode till/lake deposits. GS2 is interpreted as the outwash gravel deposit associated with G2. GS2 also likely includes coarse talus or slump deposits associated with the steep bedrock valley walls.

The Henry Formation has an average thickness of $25 \mathrm{~m}$ throughout the study site. At the location of MARN-10-052, the thickness of the Henry Formation includes the thickness of the Beverly Tongue, Tiskilwa Formation, and Ashmore Tongue because the interconnected relationship of these units is difficult to differentiate in the model domain. The thickest deposits of the Henry Formation are located along the eastern edge of the domain (Figure 9). The presence of all three units likely explains why the Henry Formation appears to be

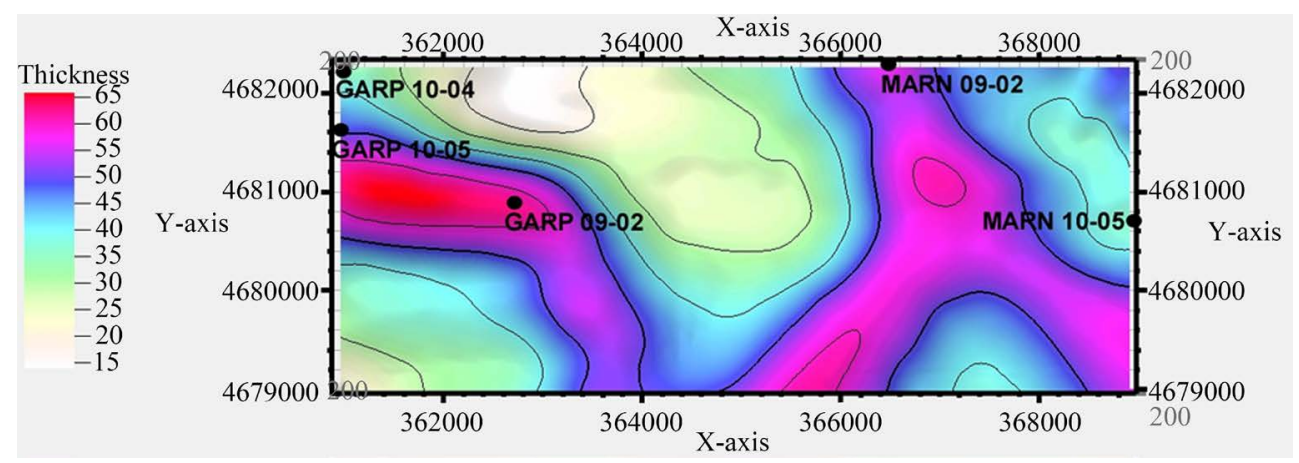

Figure 8. Isopach map of surficial deposits, contour interval $5 \mathrm{~m}$. The geometry of the upper Troy Bedrock Valley channel is evident. $\mathrm{X}$ and $\mathrm{Y}$ dimensions are UTM grid lines.

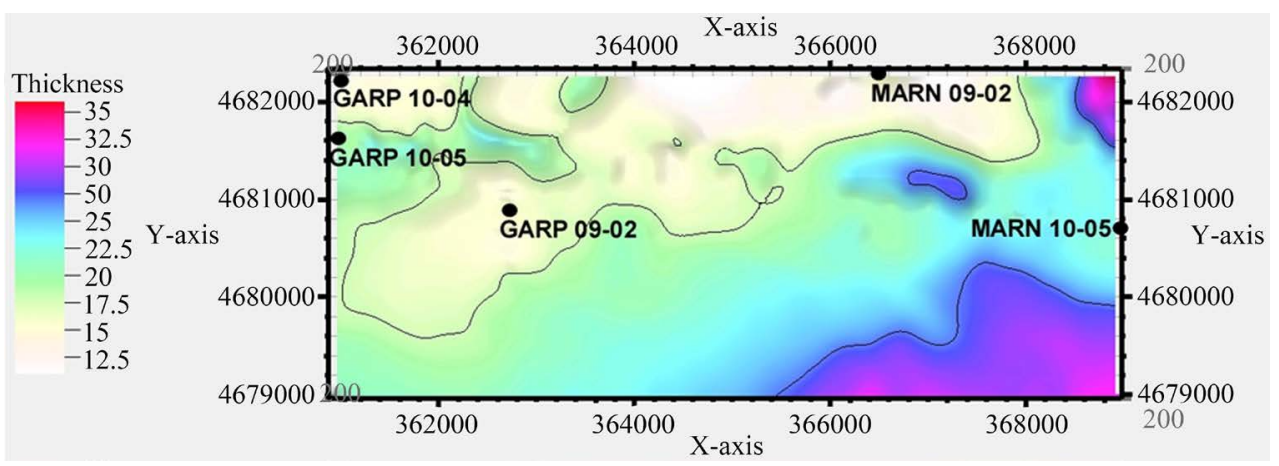

Figure 9. Isopach map of the Henry Formation. 5 control borings symbolized as black dots. Thickness is in meters. X and Y dimensions are UTM grid lines. 
thicker. The Beverly Tongue and Ashmore Tongue of the Henry Formation are also sand and gravel outwash deposits and reach a maximum thickness of about 3 m near MARN 10-05. The Tiskilwa Formation is another unit that is only present in MARN 10-05, where it reaches a maximum thickness of about $4 \mathrm{~m}$.

G1 is located throughout much of the study area but often pinches out on bedrock highs (Figure 10). The thickest deposit of G1 is about $15 \mathrm{~m}$ and occurs as a bullseye located in the bedrock valley just north of GARP 09-02, a location where seismic data have been interpreted. The interpretation is that at this location, G1 occurs as a slump deposit. Because this data point is based solely on the interpretation of seismic data, model confidence at this point is low. GS1 is located mostly in the northern half of the study area and also pinches out along bedrock highs (Figure 11).

The majority of G2 is located in the northern two thirds of the study site and follows the bedrock surface. In the north-central part of the mapping area, G2 is absent because of a bedrock high. However, G2 is deposited on the southern half of that same bedrock high. It reaches a maximum thickness of $28 \mathrm{~m}$ in the bedrock valley (Figure 12). GS2 is completely contained within the lowest parts of the bedrock valley. It very closely mirrors the bedrock surface and reaches a maximum thickness of $20 \mathrm{~m}$ (Figure 13).

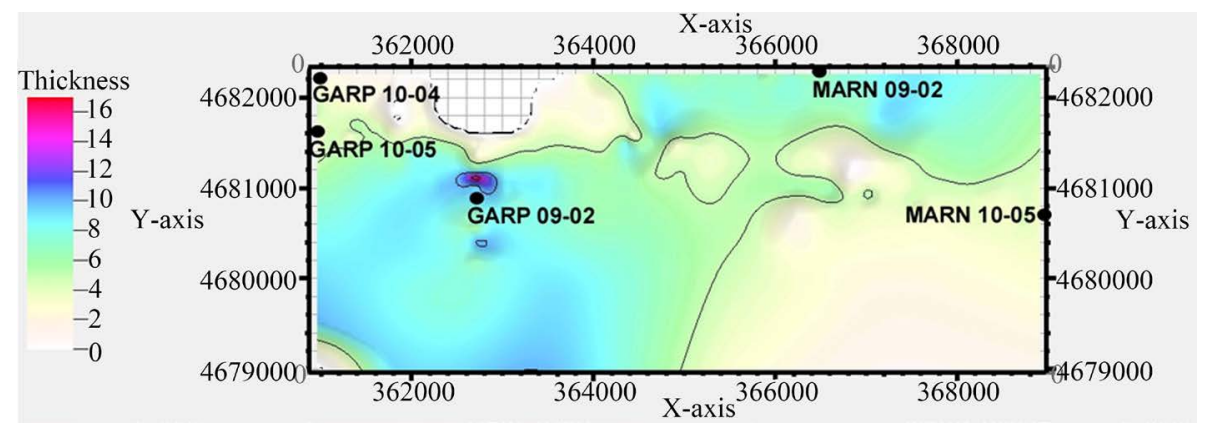

Figure 10. Isopach map of G1. 5 control borings symbolized as black dots. Thickness is in meters. X and Y dimensions are UTM grid lines.

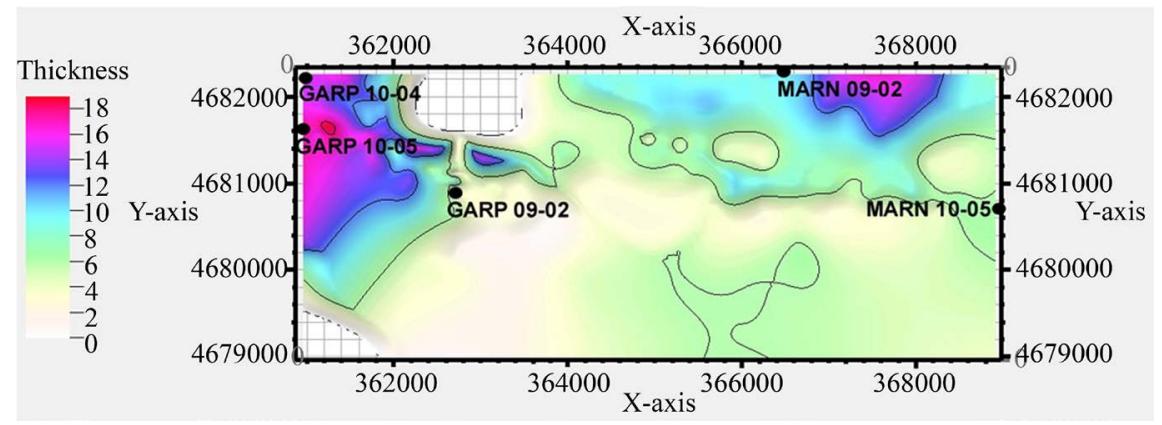

Figure 11. Isopach map of GS1. 5 control borings symbolized as black dots. Thickness is in meters. X and Y dimensions are UTM grid lines.

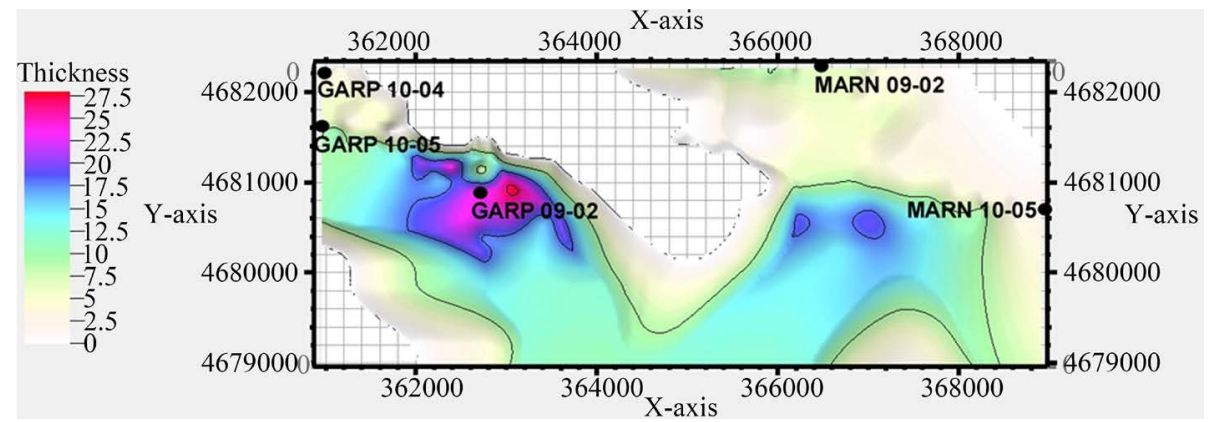

Figure 12. Isopach map of G2. 5 control borings symbolized as black dots. Thickness is in meters. X and Y dimensions are UTM grid lines. 


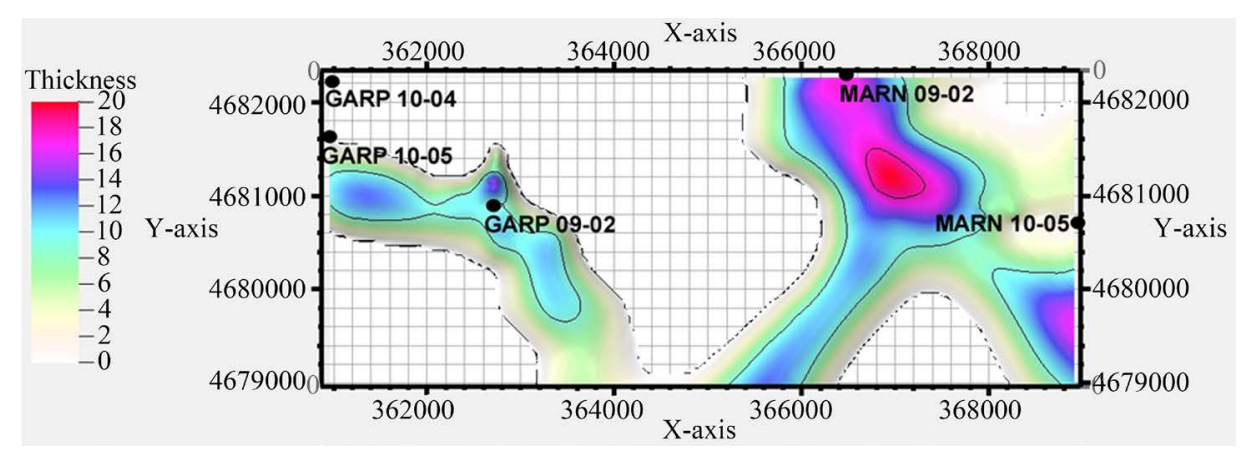

Figure 13. Isopach map of GS2. 5 control borings symbolized as black dots. Thickness is in meters. X and Y dimensions are UTM grid lines.

\subsection{Troy Buried Bedrock Valley}

The Silurian bedrock surface has significant paleotopographic relief. The Troy Bedrock Valley (TBV) is a major preglacial bedrock valley that enters Illinois from Wisconsin and continues in a south-west trend in to Boone County [6]. During the Pleistocene, the valley was filled with outwash, till, and alluvial deposits that range in thickness from tens of meters to several hundreds of meters. The TBV has no expression at land surface [48]. In areas where Quaternary units are in contact with the bedrock, the bedrock aquifer and the Quaternary aquifer are hydrogeologically connected [19]. The bedrock valley in this study area (Figure 14) is an ancestral tributary valley to the Troy River Valley. The events and constraints that controlled the development of the steep-sided TBV [6] are applicable to the local bedrock valley in this study.

\subsection{Early Illinois Episode Sequence (GS2 and G2 Deposition)}

As glaciers from the Illinois Episode (190,000 to 130,000 years before present) advanced across the study site, coarse grained sediments of GS2 were deposited. GS2 is interpreted as proglacial outwash deposits that were deposited from glacial meltwater as the glacier advanced from the east and north (Figure 15). Abundant meltwater provided the high energy necessary to transport large volumes of sand and gravel into the bedrock valley.

Deposition of the coarse sand and gravel of GS2 ended when the drainage pattern of the bedrock valley changed and the glacial margin overrode the area, thus depositing a thin diamicton unit (3 - 4 meters thick) associated with unit G2 [6]. Lacustrine sediments of G2 suggest that during part of the Illinois Episode of glaciation, when the glacial ice was far away from the study site, the drainage through the bedrock valley system (which includes the TBV) may have been blocked due to another ice lobe to the west (or south), or perhaps the drainage was blocked between proglacial moraines and the ice front. It is unknown what caused a blockage (Figures 16); the resultant ponding led to the deposition of 10 - $15 \mathrm{~m}$ of laminated silt and clay. Where present, this lake deposit acts as an aquitard that impedes groundwater flow between GS1 and GS2.

\subsection{Late Illinois Episode Sequence (GS1 and G1 Deposition)}

At the location of boring GARP 09-02, GS1 is $6 \mathrm{~m}$ thick and is described as a coarse gravel with rounded pebbles. Traceable within the 2D geophysical profiles, GS1 is interpreted as proglacial outwash that was deposited by a younger glacial advance (younger than the G2 advance) through the study area (Figure 17). G1 contains till likely associated with Oregon Member and marks a period of glacial ice advancement into the bedrock valley (Figure 18).

The thickest deposits of G1, about $16 \mathrm{~m}$, are located in the bedrock valley along the Thorne Rd. seismic line where a slump deposit is interpreted. G1 sediments may be thicker here simply because glacial deposits tend to be thicker in bedrock valleys [6]. This thickness may also be attributed to a buried moraine [14] or random variability of thickness associated with local subglacial deposition/erosion.

\subsection{Wisconsin Episode Glaciofluvial Deposition}

The Henry Formation is present across nearly the entire mapping area and is interpreted as proglacial outwash sediments associated with the last advance and retreat of Wisconsin Episode glaciation (Figure 19). This unit 


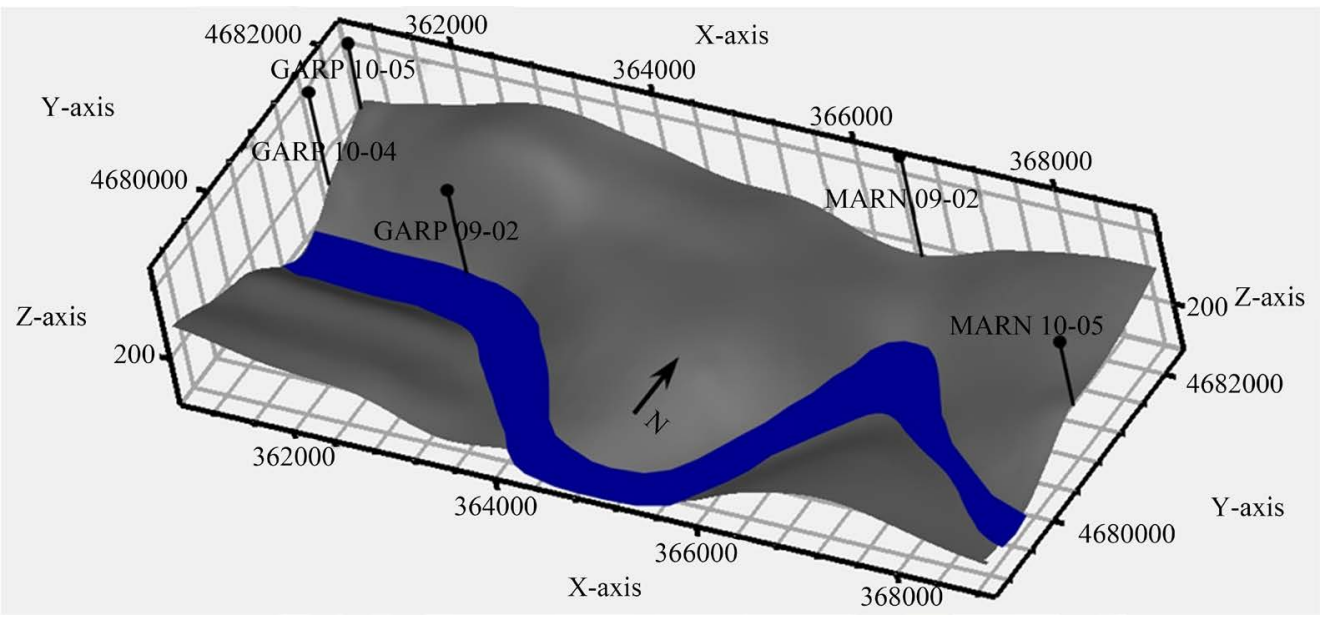

Figure 14. Structure contour map of the bedrock surface indicating the position of the tributary to the TBV. X and Y dimensions are UTM grid lines.

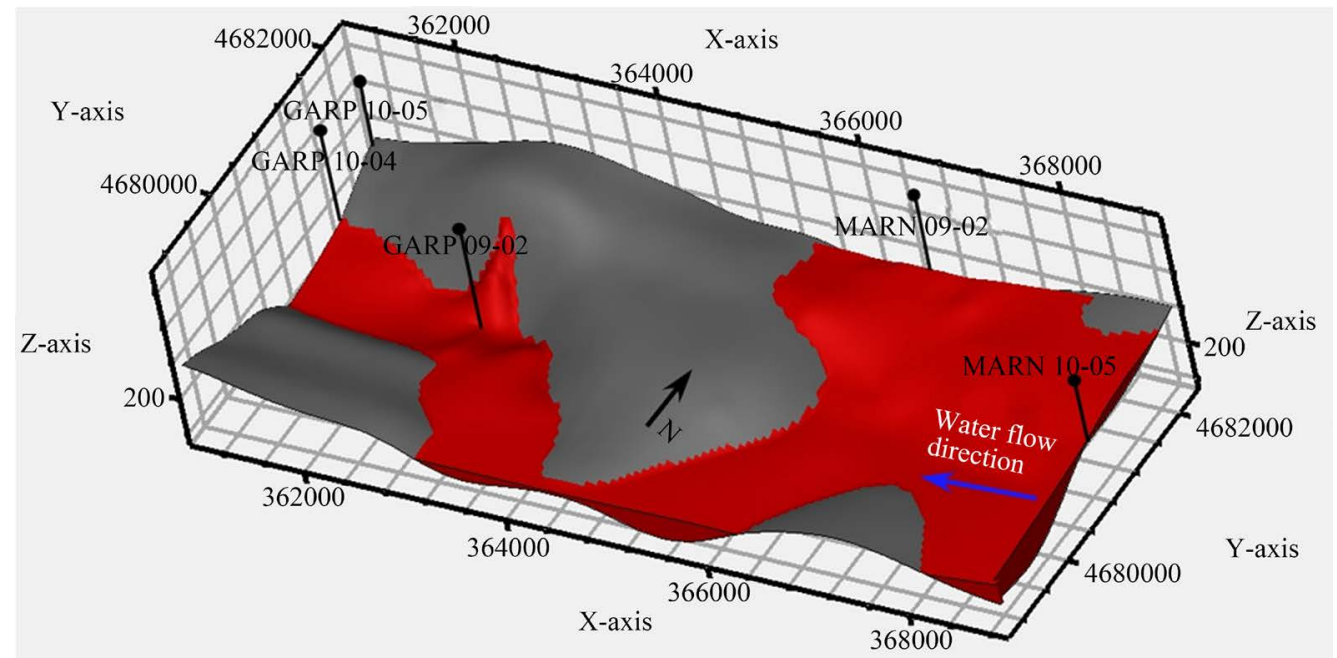

Figure 15. Structure contour map of GS2. X and Y dimensions are UTM grid lines.

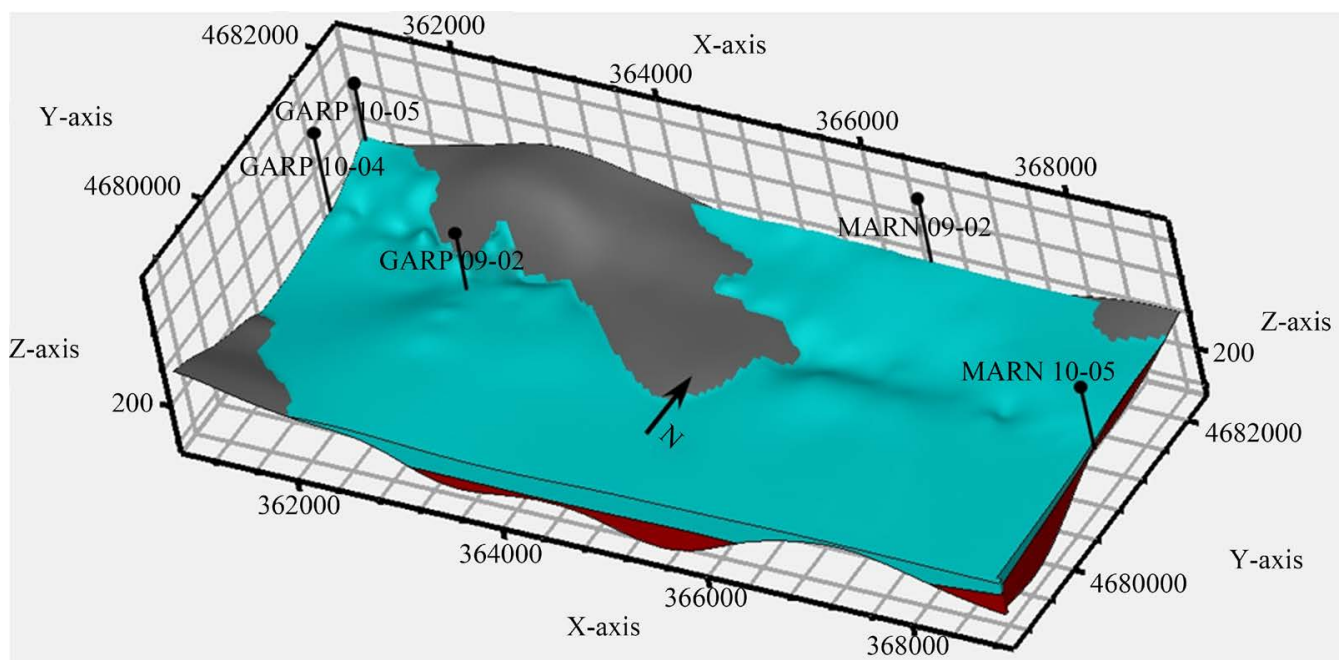

Figure 16. Structure contour map of G2. X and Y dimensions are UTM grid lines. 


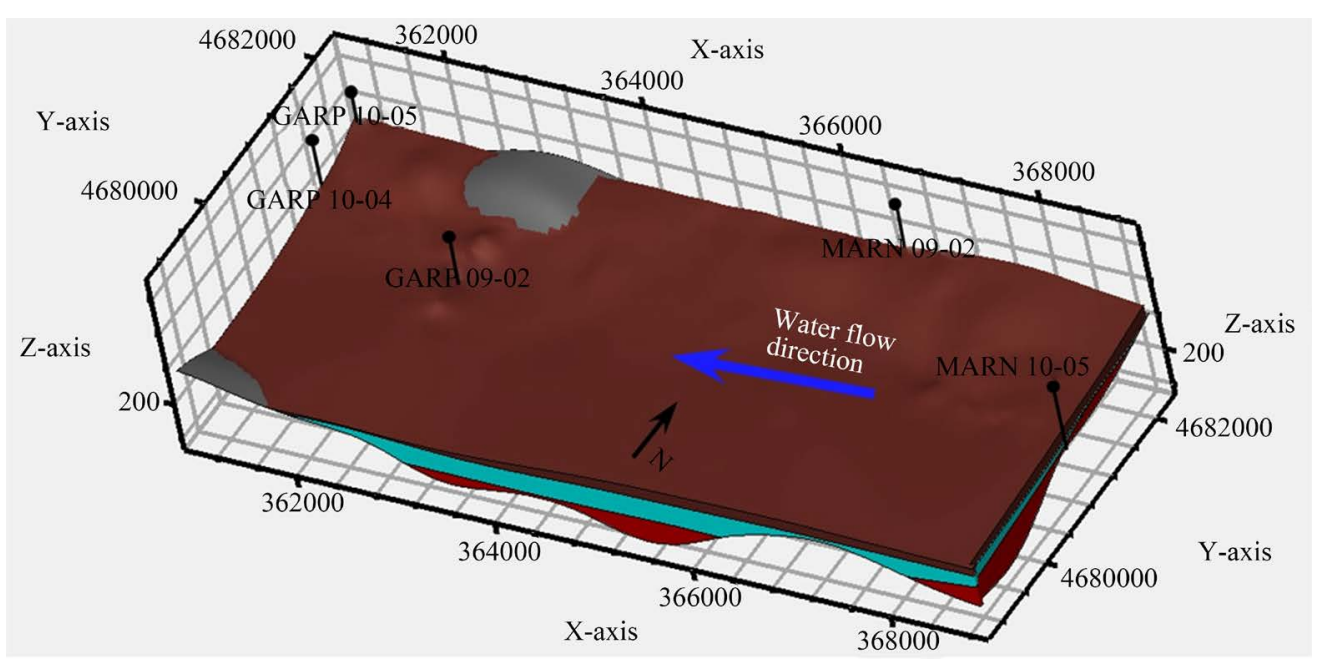

Figure 17. Structure contour map of GS1. X and Y dimensions are UTM grid lines.

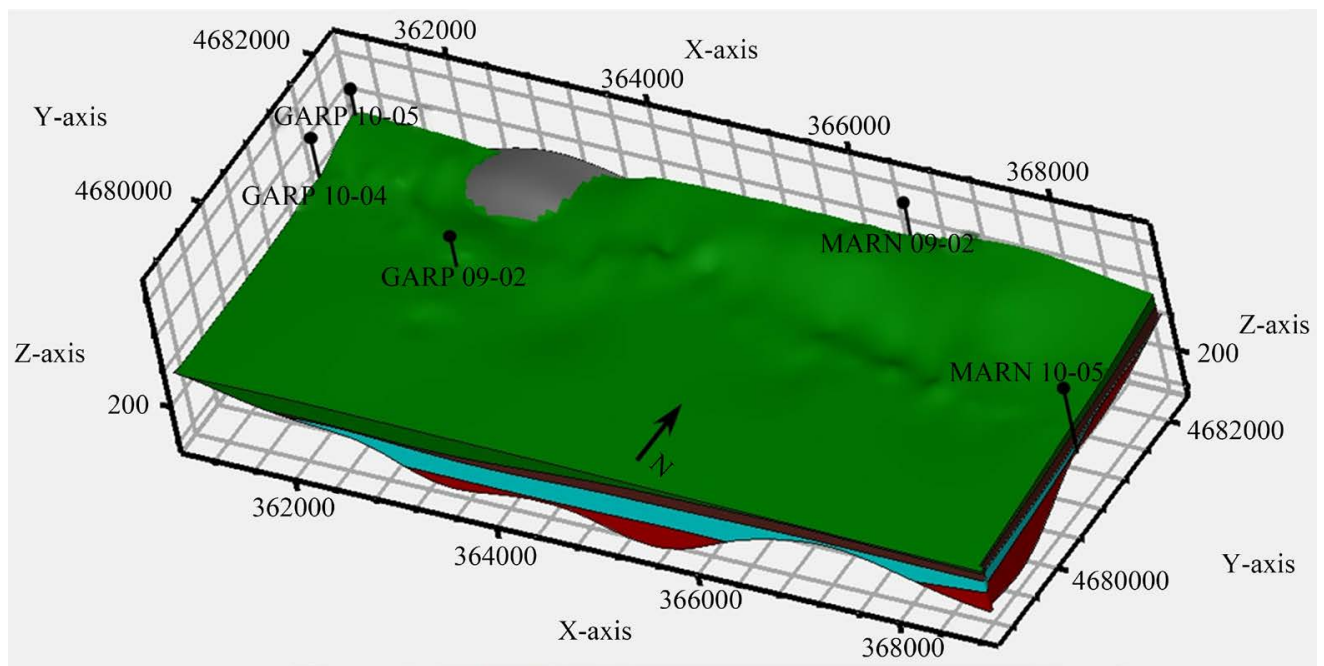

Figure 18. Structure contour map of G1. X and Y dimensions are UTM grid lines.

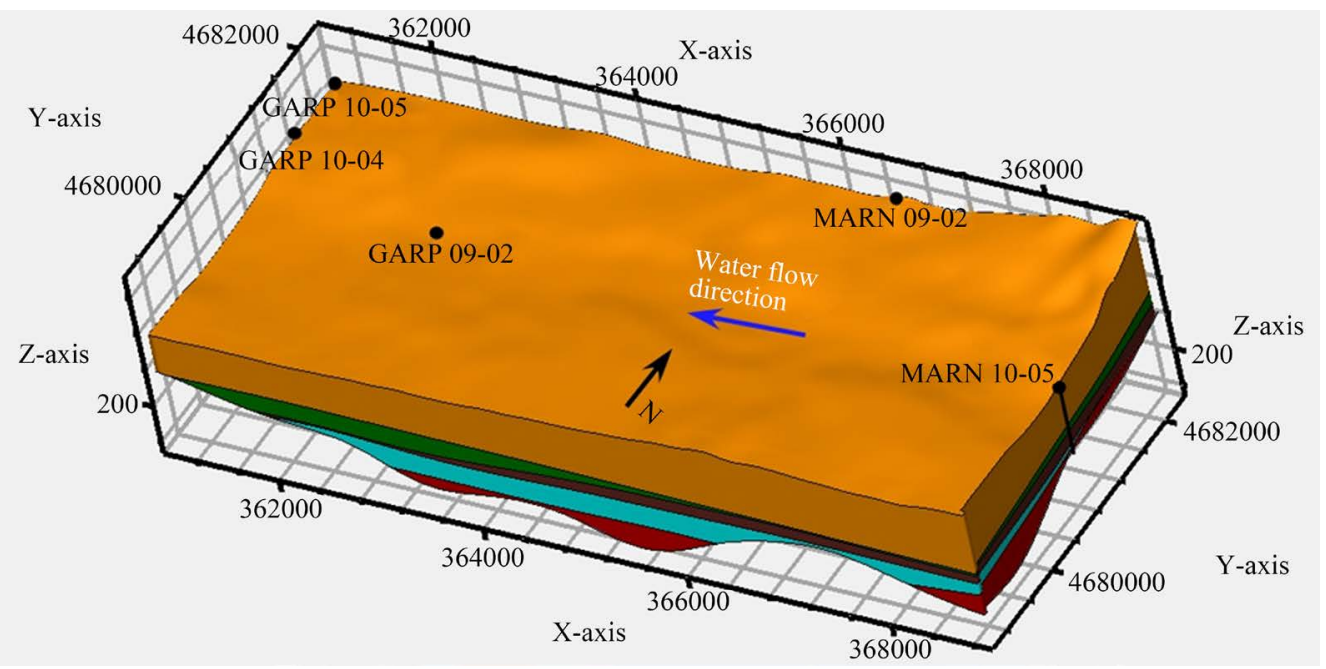

Figure 19. Structure contour map of Hen1. X and Y dimensions are UTM grid lines. 
may also include outwash deposits associated with the retreat of older glaciations, but differentiating between those units is difficult.

The Cahokia Formation, the modern alluvium and flood plain deposits present along the Kishwaukee River, was grouped with the Henry Formation to simplify the model. Within the Kishwaukee River valley, the Henry Formation interfingers with the Beverly Tongue, the Tiskilwa Formation, and the Ashmore Tongue. MARN 09-02 contains a more complex assemblage of near surface sediments because of the nature of its location. It is situated near the base of a modern regional slope, where thinner deposits of valley fill and colluvial sediments have been deposited throughout at least the Wisconsin Episode and Holocene.

\section{Conclusion}

Detailed 3D geologic mapping and hydrogeologic investigation within a buried bedrock valley in McHenry County provided insight into the local hydrogeologic flow system. Continuous-core geologic borings and highresolution 2D geophysical profiles provided control data for geologic mapping. These data provided the framework to build a reasonable 3D geologic model of the extent, distribution, thickness, and contact relationships of the Quaternary lithostratigraphic units. The orientation and geometry of the units are consistent with lithologies observed in the main Troy Bedrock Valley. While the Henry Outwash has an average thickens of $24 \mathrm{~m}$, the inclusion of the Tiskilwa Formation within the Henry Formation suggests that it may not serve as a suitable source of water. The sands and gravels of the upper Glasford (GS1) are relatively thin in the area and with the exception of localized areas (northwestern corner of study area) would not be a sustainable aquifer. Following the valley floor, the lower sands and gravels of the Glasford (GS2) are thicker than the GS1 layer. However, the thickness is not uniform, and layer thins to less than $6 \mathrm{~m}$ in the southern edge of the domain. The tributary does not appear to have the storage necessary to serve as a water resource.

\section{References}

[1] Dalrymple, R.W., Boyd, R. and Zaitlin, B.A. (2010) History of Research, Types and Internal Organization of IncisedValley Systems: Introduction to the Volume. Incised-Valley Systems: Origin and Sedimentary Sequences, 1, 3-10.

[2] Gabriel, G., Kirsch, R., Siemon, B. and Wiederhold, H. (2003) Geophysical Investigation of Buried Pleistocene Subglacial Valleys in Northern Germany. Journal of Applied Geophysics, 53, 159-180. http://dx.doi.org/10.1016/j.jappgeo.2003.08.005

[3] Jorgensen, F., Lykke-Andersen, H., Sandersen, P.B.E., Auken, E. and Normark, E. (2003) Geophysical Investigations of Buried Quaternary Valleys in Denmark: An Integrated Application of Transient Electromagnetic Soundings, Reflection Seismic Surveys and Exploratory Drillings. Journal of Applied Geophysics, 53, 215-228. http://dx.doi.org/10.1016/j.jappgeo.2003.08.017

[4] Sanderson, E.W. (1971) Groundwater Availability in Piatt County. Illinois State Geological Survey Circular, 107, 183.

[5] Sanderson, E.W. and Zewde, E. (1976) Groundwater Availability in Champaign County. Illinois State Geological Survey Circular, 124, 1-139.

[6] Vaiden, R., Smith, E.C. and Larson, T.H. (2004) Groundwater Geology of DeKalb County, Illinois with Emphasis on the Troy Bedrock Valley. Illinois State Geological Survey Circular, 563, 1-39.

[7] Visocky, A.P. and Schicht, R.J. (1969) Groundwater Resources of the Buried Mahomet Bedrock Valley. Illinois State Water Survey Report of Investigation, 62, 1-52.

[8] Willems, B.A., Malone, D.H. and Pugin, A. (2007) Geologic Characteristics of the Central Stretch of the Ticona Channel, North-Central Illinois. Environmental Geosciences, 14, 123-136. http://dx.doi.org/10.1306/eg.05030606002

[9] Kempton, J.P., Johnson, W.H., Heigold, P.C. and Cartwright, K. (1991) Mahomet Bedrock Valley in East-Central Illinois: Topography, Glacial Drift Stratigraphy, and Hydrogeology. Geological Society of America Special Paper, 258, 91-124. http://dx.doi.org/10.1130/SPE258-p91

[10] Ritzi Jr., R.W., Jayne, D.F., Zahradnik Jr., A.J., Field, A.A. and Fogg, G.E. (1994) Geostatistical Modeling of Heterogeneity in Glaciofluvial, Buried-Valley Aquifers. Ground Water, 32, 666-674. http://dx.doi.org/10.1111/j.1745-6584.1994.tb00903.x

[11] Ritzi Jr., R.W., Dominic, D.F., Slesers, A.J., Greer, C.B., Reboulet, E.C., Telford, J.A., Masters, R.W., Klohe, C.A., Bogle, J.L. and Means, B.P. (2000) Comparing Statistical Models of Physical Heterogeneity in Buried-Valley Aquifers. Water Resources Research, 36, 3179-3192. http://dx.doi.org/10.1029/2000WR900143

[12] Berg, R.C., Kempton, J.P., Stecyk, A.N., Goodwin, J.H. and Glockner, M. (1984) Geology for Planning in Boone and 
Winnebago Counties. Illinois State Geological Survey Circular, 531, 1-64.

[13] Kempton, J.P. (1963) Subsurface Stratigraphy of the Pleistocene Deposits of Central Northern Illinois. Illinois State Geological Survey Circular, 356, 1-43.

[14] Alden, W.C. (1904) The Delavan Lobe of the Lake Michigan Glacier of the Wisconsin Stage of Glaciation and Associated Phenomena. United States Geological Survey Professional Paper, 34, 1-99.

[15] Green, J. (1968) The Troy Valley of Southeastern Wisconsin. United States Geological Survey Professional Paper, 600-C, 135-139.

[16] Horberg, L. and Anderson, R.C. (1956) Bedrock Topography and Pleistocene Glacial Lobes in Central United States. Journal of Geology, 64, 101-116. http://dx.doi.org/10.1086/626328

[17] Horberg, L. (1950) Bedrock Topography of Illinois. Illinois State Geological Survey Bulletin 73, 1-23.

[18] McKinney, C. (2011) Update on Water Studies Groundwater Protection Program. Division of Water Resources, County of McHenry, 8 p.

[19] Curry, B.B., Berg, R.C. and Vaiden, R.C. (1997) Geologic Mapping for Environmental Planning. Illinois State Geological Survey Circular 559, McHenry County, Illinois, 1-44.

[20] Hwang, H.H., Panno, S.V., Hackley, K.C. and Walgren, D. (2007) Chemical and Isotopic Database for McHenry County Study on Groundwater Quality and Land Use. Illinois State Geological Survey Open File Report 2007-6, 1-26.

[21] Cutler, P.M., Colgan, P.M. and Mickelson, D.M. (2002) Sedimentologic Evidence for Outburst Floods from the Laurentide Ice Sheet Margin in Wisconsin, USA: Implications for Tunnel-Channel Formation. Quaternary International, 90, 23-40. http://dx.doi.org/10.1016/S1040-6182(01)00090-8

[22] Fricke, C. and Johnson, T. (1983) The Pleistocene Stratigraphy and Geomorphology of Central-Southern Wisconsin and Part of Northern Illinois. Geoscience Wisconsin, 8, 22-44.

[23] Mickelson, D.M., Clayton, L., Baker, R.W., Mode, W.N. and Schneider, A.F. (1984) Pleistocene Stratigraphic Units of Wisconsin. Wisconsin Geological and Natural History Survey Miscellaneous Paper 84-1.

[24] Mickelson, D.M. and Colgan, P.M. (2003) The Southern Laurentide Ice Sheet. Development in Quaternary Science, 1, 1-16. http://dx.doi.org/10.1016/S1571-0866(03)01001-7

[25] Syverson, K.M. and Colgan, P.M. (2000) The Quaternary of Wisconsin: A Review of Stratigraphy and Glaciation History. In: Ehlers, J. and Gibbard, P.L., Eds., Quaternary Glaciations-Extent and Chronology, Part II: North America, Developments in Quaternary Science, Vol. 2b, Elsevier, Amsterdam, 295-306.

[26] Syverson, K.M., Clayton, L., Attig, J.W. and Mickelson, D.M. (2011) Lexicon of Pleistocene Stratigraphic Units of Wisconsin, Wisconsin Geological and Natural History Survey. Madison, WI, Technical Report 1.

[27] Stumpf, A.J. and Ismail, A. (2013) High-Resolution Seismic Reflection Profiling: An Aid for Resolving the Pleistocene Stratigraphy of a Buried Valley in Central Illinois, USA. Annals of Glaciology, 54, 10-20. http://dx.doi.org/10.3189/2013AoG64A602

[28] Ismail, A., Stumpf, A. and Bauer, R. (2014) Seismic Characterization of Glacial Sediments in Central Illinois. Journal of Applied Geophysics, 101, 1-10. http://dx.doi.org/10.1016/j.jappgeo.2013.11.009

[29] Ross, M., Parent, M. and Lefebvre, R. (2005) 3D Geologic Framework Models for Regional Hydrogeology and LandUse Management: A Case Study from a Quaternary Basin of Southwestern Quebec, Canada. Hydrogeology Journal, 13, 690-707. http://dx.doi.org/10.1007/s10040-004-0365-X

[30] Sharpe, D.R., Hazen, A.J.R. and Logan, C. (2007) A 3-Dimensional Geological Model of the Oak Ridges Moraine Area, Ontario, Canada. Journal of Maps, 3, 239-253. http://dx.doi.org/10.1080/jom.2007.9710842

[31] Hartz, M., Malone, D. and Nelson, R. (2016) Three-Dimensional Geologic Model of Glacial Outwash in Mclean County, Illinois, Based on Seismic Refraction Studies. Geosciences, 6, 9. http://dx.doi.org/10.3390/geosciences6010009

[32] Berg, R.C., Brown, S.E., Thomason, J.F., Hasenmueller, N.R., Letsinger, S.L., Kincare, K.A., Esch, J.M., Kehew, A.E., Thorleifson, L.H., Kozlowski, A.L., Bird, B.C., et al. (2016) A Multiagency and Multijurisdictional Approach to Mapping the Glacial Deposits of the Great Lakes Region in Three Dimensions. Geological Society of America Special Paper, 520, 415-447. http://dx.doi.org/10.1130/2016.2520(37)

[33] Attig, J.W., Mickelson, D.M. and Clayton, L. (1989) Late Wisconsin Landform Distribution and Glacier-Bed Conditions in Wisconsin. Sedimentary Geology, 62, 399-405. http://dx.doi.org/10.1016/0037-0738(89)90128-0

[34] Berg, R.C., Kempton, J.P., Follmer, L.R., McKenna, D.P. and Krumm, R.J. (1985) Illinoian and Wisconsinan Stratigraphy and Environments in Northern Illinois. The Altonian Revised, Illinois State Geological Survey Guidebook 19.

[35] Carlock, D.C., Thomason, J.F., Malone, D.H. and Peterson, E.W. (2016) Stratigraphy and Extent of the Pearl-Ashmore Aquifer, McHenry County, IL, USA. World Journal of Environmental Engineering, 4, 6-18. 
[36] Curry, B.B. and Yansa, C.H. (2004) Evidence for Stagnation of the Harvard Sublobe (Lake Michigan Lobe) in Northeastern Illinois, U.S.A. from 24000 to 17600 BP and Subsequent Tundra-Like Ice-Marginal Paleoenvironments from 17600 to 15700 BP. Géographie Physique et Quaternaire, 58, 305-321. http://dx.doi.org/10.7202/013145ar

[37] Hansel, A.K. and Johnson, W.H. (1996) Wedron and Mason Groups: A Lithostratigraphic Reclassification of Deposits of the Wisconsin Episode Lake Michigan Lobe Area. Illinois State Geological Survey Bulletin 104, 25-64.

[38] Willman, H.B. and Frye, J.C. (1970) Pleistocene Stratigraphy of Illinois. Illinois State Geological Survey Bulletin 94, $1-62$.

[39] Curry, B.B. (2005) Surficial Geology of Crystal Lake Quadrangle, McHenry and Kane Counties. Illinois State Geological Survey, Illinois, Scale 1:24,000.

[40] Curry, B.B. (2007) Bedrock topography of Elgin Quadrangle, Kane and Cook Counties. Illinois State Geological Survey, Illinois, Scale 1:24,000.

[41] Seipel, L., Peterson, E.W., Malone, D.H. and Thomason, J.F. (2016) Role of Multiple High-Capacity Irrigation Wells on a Surficial Sand and Gravel Aquifer. Journal of Geoscience and Environment Protection, 4, 43-53. http://dx.doi.org/10.4236/gep.2016.45005

[42] Seipel, L.C., Thomason, J.F., Malone, D.H. and Peterson, E.W. (2015) Surficial Geology of Garden Prairie 7.5-Minute Quadrangle, Boone and McHenry Counties. llinois State Geological Survey, Illinois, Scale 1:24,000.

[43] Stumpf, A.J., Barnhardt, M.L. and Hansel, A.K. (2004) Surficial Geology of Wauconda Quadrangle: Lake and McHenry Counties. llinois State Geological Survey, Illinois, Scale 1:24,000.

[44] Thomason, J.T. and Barnhardt, M.L. (2007) Surficial Geology of the Barrington Quadrangle, Lake, McHenry, Cook, and Kane Counties, Illinois, Scale 1:24,000.

[45] Kimple, D., Peterson, E.W. and Malone, D.H. (2015) Stratigraphy and Porosity Modeling of Southern Central Illinois Chester (Upper Mississippian) Series Sandstones Using Petrel. World Journal of Environmental Engineering, 3, 82-86.

[46] Kron, N., Malone, D.H. and Peterson, E.W. (2015) Three-Dimensional Geologic Model of the Pecatonica Gas Storage Field, Winnebago County, Illinois. World Journal of Environmental Engineering, 3,121-125.

[47] Wagle, J., Malone, D.H., Peterson, E.W. and Tranel, L. (2016) Porosity Controls on Secondary Recovery at the Loudon Field, South-Central Illinois. Interpretation, 4, T1-T13. http://dx.doi.org/10.1190/INT-2015-0078.1

[48] McGarry, C.S. (2000) Bedrock geology of Boone and Winnebago Counties. Illinois State Geological Survey Open File Report 2000-03, Illinois.

\section{Submit or recommend next manuscript to SCIRP and we will provide best service for you:}

Accepting pre-submission inquiries through Email, Facebook, Linkedin, Twitter, etc

A wide selection of journals (inclusive of 9 subjects, more than 200 journals)

Providing a 24-hour high-quality service

User-friendly online submission system

Fair and swift peer-review system

Efficient typesetting and proofreading procedure

Display of the result of downloads and visits, as well as the number of cited articles

Maximum dissemination of your research work

Submit your manuscript at: http://papersubmission.scirp.org/ 